\title{
GLYCOGEN AND RELATED ENZYMES IN NORMAL AND CRYPTORCHID HUMAN TESTES: A CYTOCHEMICAL STUDY
}

\author{
ADRIANA SEILICOVICH AND ANIBAL PÉREZ LLORET \\ Centro de Investigaciones en Reproducción, Facultad de Medicina, \\ Paraguay 2155-piso 10-Buenos Aires, Argentina
}

(Received 4th April 1972)

\begin{abstract}
Summary. Cytochemical studies were carried out on normal and cryptorchid human testes in order to define the distribution of glycogen and some related enzymes during testicular maturation. The glycogen content, and phosphorylase and amylo 1-4,1-6 transglucosidase activities increased in the seminiferous tubules of scrotal testes with maturation. Weaker reactions were always obtained in cryptorchid testes. Phosphorylase and amylo 1-4,1-6 transglucosidase activities were detected in some cells in the intertubular spaces. The localization of these enzymes in scrotal and cryptorchid testes differed at different ages. It was not possible to demonstrate the presence of glycogen synthetase. The rôle played by these glycogen metabolism enzymes in the testis is discussed.
\end{abstract}

\section{INTRODUCTION}

The presence of glycogen has been demonstrated in the seminiferous tubule of the adult human testis (Arzac, 1950; Elftman, 1952; Long \& Engle, 1952; Montagna, 1952; Mancini, Nolazco \& De la Balze, 1952) and its distribution has been shown to vary with testicular maturation (Mancini, Rosemberg, Cullen, Lavieri, Vilar, Bergadá \& Andrada, 1965; Fabbrini, Re \& Conti, 1969). Chemical and cytochemical studies involving rat testis have tended to confirm this finding (Leiderman \& Mancini, 1969).

Several enzymes related to glycogen metabolism have been studied in normal and pathological human testes (Fabbrini, Re \& Spera, 1968, 1969), but the evolution of glycogen enzyme activity in the course of human gonadal maturation has not so far been reported.

\section{MATERIALS AND METHODS}

Five unilaterally cryptorchid patients aged 4 to 11 years, with no endocrinological disturbances, were selected. Biopsies were performed on the undescended and contralateral scrotal testes.

Tissues were either fixed in Cleland's mixture for the study of general morphology and polysaccharides, or frozen in solid carbonic anhydride for enzymatic studies. The fixed sections were stained with haematoxylin and eosin 
for morphological studies and with periodic acid Schiff (PAS) reaction, controlled by incubation in $1 \%$ Taka-Diastasa (Parke Davis) at $37^{\circ} \mathrm{G}$ for $60 \mathrm{~min}$ for glycogen studies.

Cytochemical reactions for the demonstration of phosphorylase (Eränkö \& Palkama, 1961), amylo 1-4,1-6 transglucosidase (Takeuchi, 1958), and glycogen synthetase (Takeuchi \& Glenner, 1961; Sie, Sawyer \& Fishman, 1966) were used. The specificity of the enzymatic reactions was checked in similar reactions in which the tissue was incubated for an equal period of time in control solutions to which no specific substrates were added.

Identification of the different germinal cells was made in accordance with the nomenclature proposed by Clermont (1963). Testicular biopsies were classified into 'Infantile' and 'Pubertal' with reference to the histological characteristics of normal scrotal testes.

\section{RESULTS}

\section{Infantile testis}

In the seminiferous tubules, infantile scrotal testes contained immature Sertoli cells and a germinal cell line composed only of spermatogonia. No mature Leydig cells were observed in the intertubular spaces.

Cryptorchid testes had small seminiferous tubules which contained immature Sertoli cells and spermatogonia. Leydig cells were not present.

Glycogen was detected in the scrotal testes in various amounts in the different types of spermatogonial cells, as well as in the elongated peritubular cells (Pl. 1, Fig. 1). Material which was PAS-positive but which was not digested by TakaDiastasa was observed in some interstitial cells which could be identified as fibroblast-like cells.

Brown or violet granules, indicating a positive activity for phosphorylase, were regularly distributed in the seminiferous tubules. In some cases, the reaction was stronger in the centre of the tubules than at the basement membrane. Phosphorylase activity was also observed in the peritubular cells and in some cells of the intertubular spaces.

A positive reaction for amylo 1-4,1-6 transglucosidase was present in both tubular and peritubular cells, but absent in the interstitial space.

Cryptorchid testes showed a weak reaction for glycogen in the tubular and peritubular cells (Pl. 1, Fig. 2). Only a weak phosphorylase activity was observed in the tubules of the younger patients, and a weak reaction was also observed in the peritubular cells of the testes of the older patients in this group;

\section{EXPLANATION OF PLATE 1}

Cross-sections of human testicular biopsy material.

Fig. 1. Infantile scrotal testis showing periodic acid Schiff (PAS)-positive material in the spermatogonial and peritubular cells. PAS. $\times 900$.

Frg. 2. Infantile cryptorchid testis contralateral to that shown in Fig. 1. A weak reaction for glycogen is observed in spermatogonial and peritubular cells. PAS. $\times 900$.

Fig. 3. Pubertal scrotal testis. A strong reaction for glycogen is present in the Sertoli cells. PAS. $\times 900$.

Fig. 4. Pubertal cryptorchid testis contralateral to that shown in Fig. 3. A weak glycogen reaction is visible in the tubular and peritubular cells. PAS. $\times 900$. 


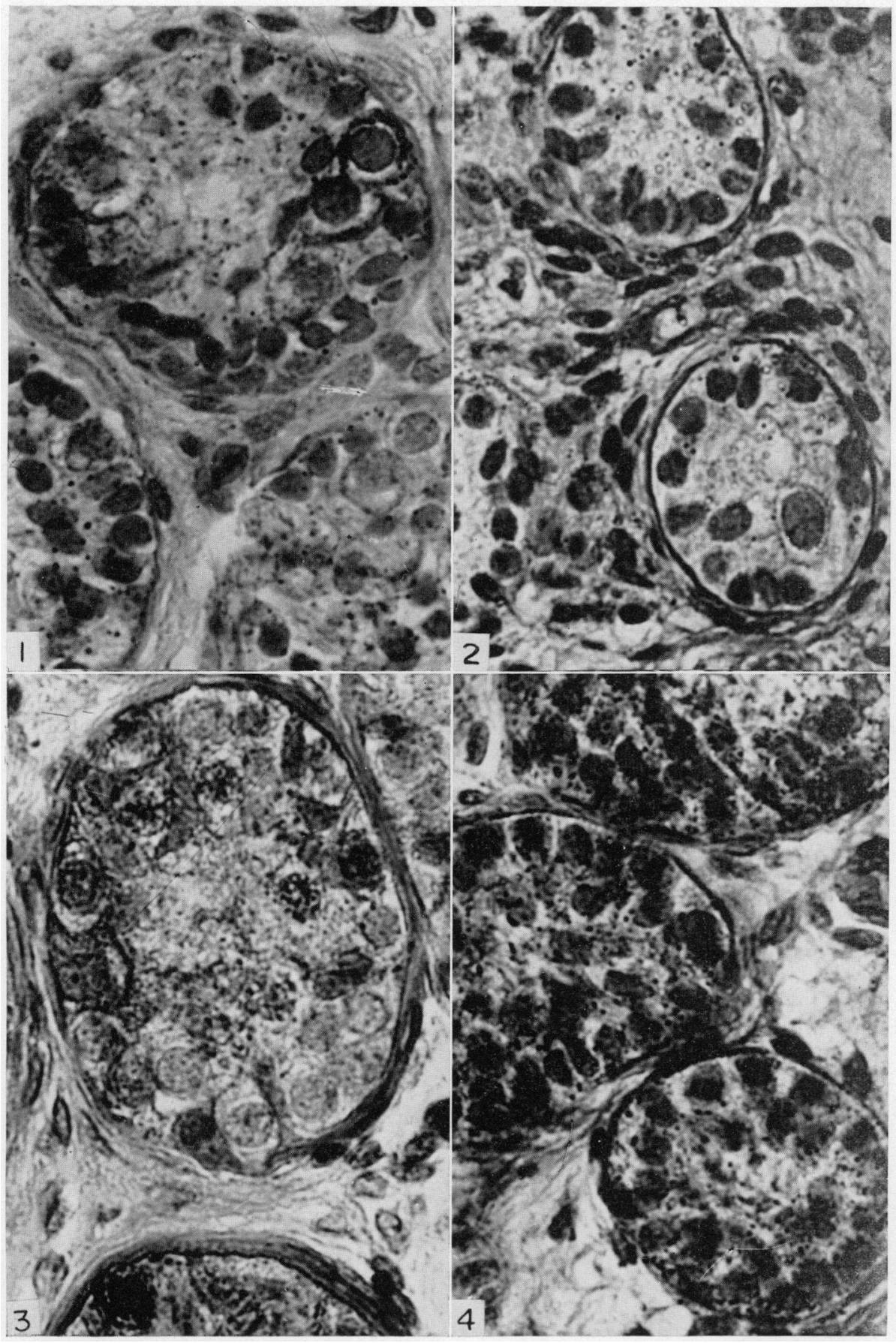




\section{PLATE 2}

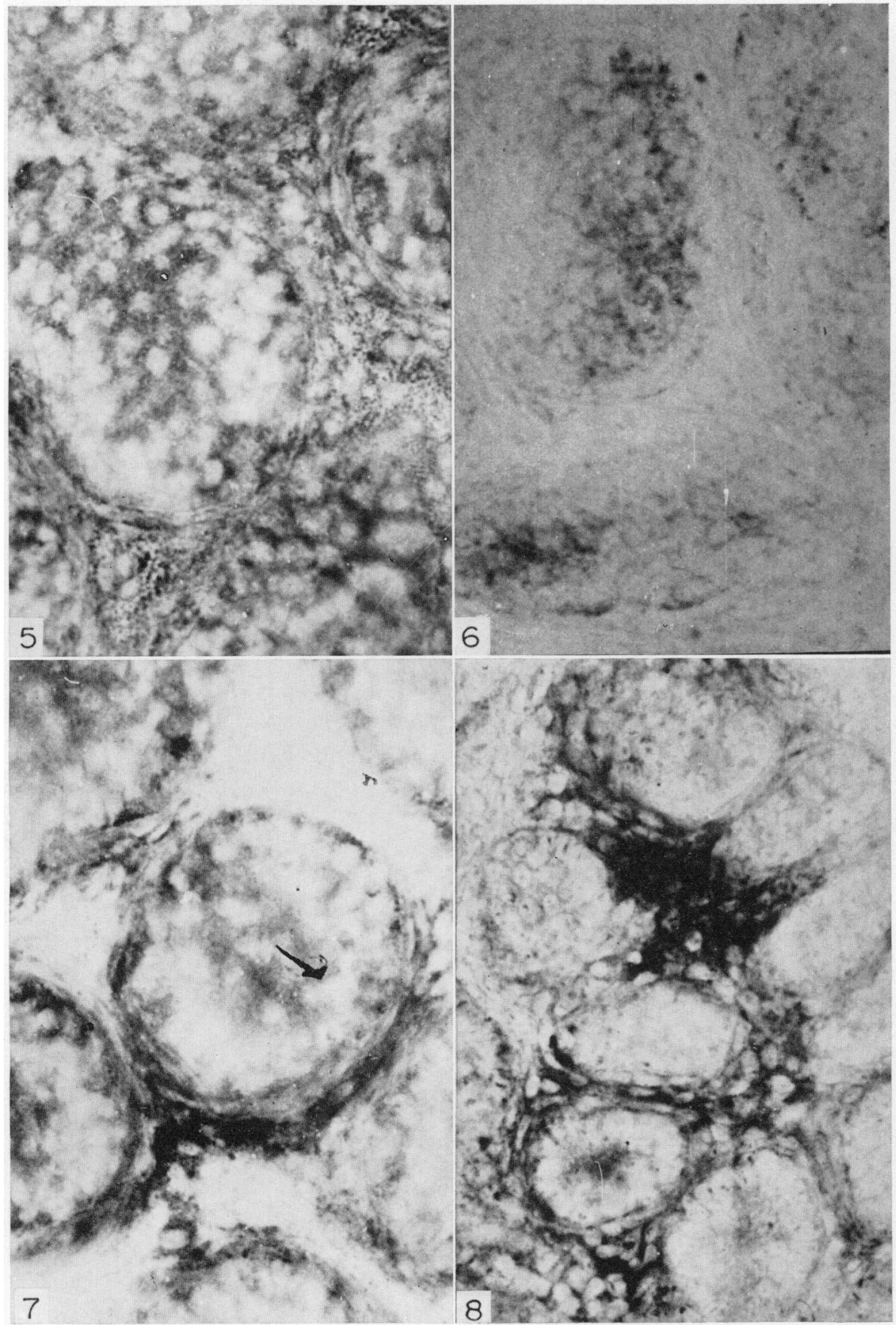

(Facing p. 381) 
no reaction was ever observed in the interstitial cells. Amylo 1-4,1-6 transglucosidase activity and localization were similar to those described in the scrotal testes.

\section{Pubertal testis}

Both mature and immature Sertoli cells, and germinal cells up to the spermatocyte stage, were observed in the seminiferous tubules of the scrotal testes. The intertubular spaces already contained some mature Leydig cells.

In the cryptorchid testes, the tubules contained immature Sertoli cells and spermatogonia, while the intertubular spaces contained mature Leydig cells.

As mature Sertoli cells appeared, glycogen deposits in the seminiferous tubules of the scrotal testes were observed to increase, though in the spermatogonial cells the reactions were weaker than in the infantile testis (Pl. 1, Fig. 3). The absence of such differences in the cryptorchid testes coincided with the absence of mature Sertoli cells (Pl. 1, Fig. 4).

Phosphorylase activity in the scrotal testes was localized in the seminiferous tubules, mainly near the basement membrane and in the peritubular and interstitial cells (Pl. 2, Fig. 5).

A scattered positive phosphorylase reaction appeared in the interstitial cells of the cryptorchid testes, the enzyme being localized as in the scrotal testes, though reactions were weaker (Pl. 2, Fig. 6).

Amylo 1-4,1-6 transglucosidase reactions were similar to those observed in infantile scrotal testes, but a striking difference was noticed in some cryptorchid testes, where this enzyme was also found in the interstitial cells (Pl. 2, Figs 7 and 8).

Glycogen synthetase activity was detected only in the muscular cells of some arteries; these cells also showed positive reactions for glycogen, phosphorylase and amylo 1-4,1-6 transglucosidase.

\section{DISCUSSION}

The observations in this study concerning the variations in glycogen distribution in the seminiferous tubules during testicular maturation agree with the available data (Mancini et al., 1952, 1965; Fabbrini, Re \& Conti, 1969). Maturation of the Sertoli cells in the scrotal testes coincided histochemically with the appearance of stronger reactions for glycogen, phosphorylase and amylo 1-4,1-6 transglucosidase, and reached a peak in the mature cells. The decrease in the

\section{EXPLANATION OF PLATE 2}

Gross-sections of human testicular biopsy material.

FIG. 5. Pubertal scrotal testis. Phosphorylase activity is present in the tubular, peritubular and interstitial cells. $\times 400$.

Fic. 6. Pubertal cryptorchid testis contralateral to that shown in Fig. 5. A weak reaction for phosphorylase is present in the tubular and peritubular cells. $\times 400$.

Fig. 7. Pubertal scrotal testis of same patient (cf. Fig. 5). Amylo 1-4,1-6 transglucosidase is observed in the tubular and peritubular cells. $\times 400$.

Fig. 8. Pubertal contralateral cryptorchid testis of same patient (cf. Fig. 6). A weak reaction for amylo 1-4,1-6 transglucosidase is visible in the seminiferous tubules, while a strong reaction is present in the intertubular spaces. $\times 400$. 
glycogen content of the pubertal spermatogonial cells coincided with active cellular division and the beginning of the meiotic process.

Weaker reactions for glycogen and phosphorylase in the seminiferous tubules of cryptorchid testes may be due mainly to the immaturity of the Sertoli cells at the prepubertal and pubertal ages. As has been suggested, the Sertoli cells may behave not only as a support but also as a bridge between the material circulating in the interstitial space and the germinal cells (Vilar, Pérez del Cerro \& Mancini, 1962). The Sertoli cells may be the main energy source for those spermatocytes and spermatids included in their cellular body (Fabbrini, $\operatorname{Re} \&$ Conti, 1969). Glycogen is an important energy source for normal spermatogenesis, and the altered behaviour of the Sertoli cells may increase the damage sustained by the germinal epithelium of cryptorchid testes at puberty.

The cytochemical behaviour of the peritubular fibroblast-like cells differed from that of the intertubular population. A correlation between the presence of phosphorylase and the maturation of the peritubular cells is suggested by the later enzymatic activity in cryptorchid testes as compared to that in scrotal ones.

The presence of glycogen in the interstitial cells has been denied by several authors (Elftman, 1952; Long \& Engle, 1952; Montagna, 1952). Arzac (1950), however, observed PAS-positive material which could be digested by amylase in the interstitium of infertile patients. A positive phosphorylase activity has been described in some Leydig cells of normal adult testes (Fabbrini et al., 1968). In our studies, the presence of phosphorylase activity in Leydig cells suggests that they are capable of metabolizing glycogen.

Based on the observation that no ostensible morphological differences appeared in the mature Leydig cells of scrotal and cryptorchid testes, it is suggested that the cytochemical behaviour of the pubertal cryptorchid testis may reflect a functional disturbance in the carbohydrate metabolism of the Leydig cells. Although a connection between the enzymes of glycogen metabolism and steroid biosynthesis has been postulated (Haynes \& Berthet, 1957; Haynes, 1958; Murad, Strauch \& Vaughan, 1969), the rôle played by these enzymes in Leydig cell metabolism has not been established, nor has the relationship between the deficient androgenic production by cryptorchid testes (Llaurado \& Dominguez, 1963; Lederer \& Bataille, 1967; Inano \& Tamaoki, 1968) and glycogen metabolism.

\section{AGKNOWLEDGMENTS}

The advice of Professor R. E. Mancini is gratefully acknowledged. The authors were supported by a grant from The Population Council Inc., New York. The testicular biopsies were kindly provided by Dr C. Bergadá from the Department of Endocrinology, Children's Hospital, Buenos Aires.

\section{REFERENGES}

ARzAc, J. P. (1950) Glycogen in human testicular biopsy material. f. clin. Endocr. Metab. 10, 1456. Clermont, Y. (1963) The cycle of the seminiferous epithelium in man. Am. F. Anat. 112, 35.

ElftMan, H. (1952) In: Studies on Testis and Ovary, Eggs and Sperm, p. 26. Ed. E. T. Engle. Charles C. Thomas, Springfield, Illinois. 
ERÄnxö, O. \& Palkama, A. (1961) Improved localization of phosphorylase by the use of polyvinyl pyrrolidone and high substrate concentration. 7. Histochem. Cytochem. 9, 585.

Fabbrint, A., RE, M. \& Conti, C. (1969) Glycogen in the normal human testis. F. Endocr. 43, 499.

FABbrini, A., RE, M. \& Spera, G. (1968) Histochemical demonstration of 1.4 amylophosphorylase in the human under normal and pathological conditions. Experientia, 24, 789.

Fabbrini, A., Re, M. \& Spera, G. (1969) Behaviour of glycogen and related enzymes in the Sertoli cell syndrome. Experientia, 25, 647.

HAyNes, R. G., JR (1958) The activation of adrenal phosphorylase by the adrenocorticotrophic hormone. F. biol. Chem. 233, 1220.

Haynes, R. G., JR \& Berthet, L. (1957) Studies on the mechanism of action of the adrenocorticotrophic hormone. F. biol. Chem. 225, 115.

INANO, H. \& TAMAOKI, B-I. (1968) Effect of experimental bilateral cryptorchidism on testicular enzymes related to androgen formation. Endocrinology, 83, 1074.

Lederer, J. \& Batarlle, J. P. (1967) Avenir éloigné de la fonction endocrine du testicule dans cryptorchidie bilatérale. Annls Endocr. 28, 252.

Lemerman, B. \& Mancin, R. E. (1969) Glycogen content in rat testis from postnatal to adult ages. Endocrinology, 85, 607.

Llaurado, J. G. \& Dominguez, O. V. (1963) Effect of cryptorchidism on testicular enzymes involved in androgen biosynthesis. Endocrinology, 72, 292.

Long, M. E. \& Engle, E. T. (1952) Cytochemistry of the human testis. Ann. N.Y. Acad. Sci. 55, 619.

Mancini, R. E., Nolazco, J. \& De LA Balze, F. A. (1952) Histochemical study of normal adult testis. Anat. Rec. 114, 127.

Mancini, R. E., Rosemberg, E., Gullen, M., Lavieri, J. G., Vilar, O., Bergadí, G. \& Andrada, J. A. (1965) Gryptorchid and scrotal human testes; (1) cytological, cytochemical and quantitative studies. F. clin. Endocr. Metab. 25, 927.

Montagna, W. (1952) Some cytochemical observations on human testis and epididymides. Ann. N.Y. Acad. Sci. 55, 629 .

Murad, F., Strauch, D. F. \& Vaughan, N. (1969) The effect of gonadotropins on testicular adenyl cyclase. Biochim. biophys. Acta, 177, 591.

Sie, H.-G., Sawyer, D. \& Fishman, W. H. (1966) Enzymorphologic demonstration of glucose-6phosphate-dependent glycogen synthetase in mouse liver. F. Histochem. Cytochem. 14, 247.

TAKEUCHI, T. (1958) Histochemical demonstration of branching enzyme (amylo 1-4, 1-6 transglucosidase) in animal tissues. 7. Histochem. Cytochem. 6, 208.

TAKeUChI, T. \& GlenNer, G. G. (1961) Histochemical demonstration of uridine diphosphate glucoseglycogen transferase in animal tissues. 7 . Histochem. Cytochem. 9, 304.

Vilar, O., Perez del Cerro, M. I. \& Mancini, R. E. (1962) The Sertoli cell as "a bridge cell" between the basal membrane and the germinal cell. Histochemical and electronmicroscopical observation. Expl Cell Res. 27, 158. 